Southern Methodist University

SMU Scholar

Sociology Research

Sociology

6-1-2012

\title{
Unexpected Winners: The Significance of an Open-List System on Women's Representation in Poland
}

Sheri L. Kunovich

Southern Methodist University, kunovich@smu.edu

Follow this and additional works at: https://scholar.smu.edu/hum_sci_sociology_research

Part of the Family, Life Course, and Society Commons, Gender and Sexuality Commons, Inequality and Stratification Commons, Other Political Science Commons, Politics and Social Change Commons, Quantitative, Qualitative, Comparative, and Historical Methodologies Commons, Social Psychology and Interaction Commons, Sociology of Culture Commons, and the Theory, Knowledge and Science Commons

\section{Recommended Citation}

Kunovich, Sheri L., "Unexpected Winners: The Significance of an Open-List System on Women's Representation in Poland" (2012). Sociology Research. 1.

https://scholar.smu.edu/hum_sci_sociology_research/1

This document is brought to you for free and open access by the Sociology at SMU Scholar. It has been accepted for inclusion in Sociology Research by an authorized administrator of SMU Scholar. For more information, please visit http://digitalrepository.smu.edu. 
Southern Methodist University

SMU Digital Repository

Sociology Research

Sociology

6-1-2012

Unexpected Winners: The Significance of an Open-List System on Women's Representation in Poland

Sheri L. Kunovich 


\section{Unexpected Winners: The Significance of an Open-List System on Women's Representation in Poland}

\section{Sheri Kunovich}

\section{Southern Methodist University}

Scholars have debated the impact of open-list systems on women's representation. While some argue that open lists provide a unique opportunity for voters to overcome parties' bias against women, others argue that they create additional barriers. I examine several mechanisms that impact women's representation within Poland's open-list system. Results suggest that 1) voters shift women's original list placements positively across all parties over three elections; 2) these shifts are more pronounced when women's overall presence on the list and list placement are lower, regardless of party; and 3) positive shifts often result in the election of substantially more women than would have been expected. These findings add to our understanding of open-list systems by documenting variability in the effects of preferential voting across time and party in a postcommunist context. In addition, the unexpected positive effects of preferential voting in Poland add to a growing body of evidence that voters and parties on the center and right support female candidates at rates approaching or similar to parties on the left.

\section{INTRODUCTION}

$S_{\text {women. With the possible exception of quotas, the positive effect of }}^{\text {everal }}$

I would like to thank Robert M. Kunovich, Goldie Shabad, Kazimierz M. Slomczynski, Joshua Dubrow, and Anne Lincoln for helpful comments on earlier versions of this article. This research was supported by a Ford Research Fellowship through Southern Methodist University.

Published by Cambridge University Press 1743-923X/12 \$30.00 for The Women and Politics Research Section of the American Political Science Association.

(C) The Women and Politics Research Section of the American Political Science Association, 2012 doi:10.1017/S1743923X12000141 
a proportional representation (PR) system is probably the most widely accepted and understood (e.g., Matland 2005; Tremblay 2008). Recent cross-national studies, however, have called this conventional wisdom into question because they find that not all PR systems help women equally. Increasingly, researchers conclude that there are important differences in women's outcomes among closed, flexible, and open-list formats (Salmond 2006; Schmidt 2009). To date, most of the countryspecific studies have focused on explaining how closed-list PR formats benefit women (see Matland 2005 for a full discussion). Less attention has been paid to the ways in which the operation of open and flexible formats affect women in comparison to men within single countries (for recent exceptions, see Meier 2008; Schmidt 2008). In addition, there have been recent calls for research that examines women's representation in contexts outside of traditional liberal democracies (Viterna, Fallon, and Beckfield 2008) as well as over time (Paxton, Hughes, and Painter 2010).

I examine the Polish open-list system over three elections (2001, 2005, and 2007) to shed light on how an open-list system affects women's descriptive representation in a relatively new democracy. Poland has been described as a consolidating democracy with substantial voter volatility (Markowski 2008) and frequent party switching among political leaders (Shabad and Slomczynski 2004). While public support for female politicians has increased over time (Siemienska 2009), women's level of representation in the national legislature has remained stable since 2001.

Women's representation did surge from 13\% to $20 \%$ after the success of the Left in the 2001 elections and has remained at 20\%. Acknowledging the positive role that a dominant left party should have on women's representation, several researchers still noted that the increase in 2001 was more than expected. Both Siemienska (2003) and Matland (2005) concluded that the number of women elected in 2001 was positively influenced by preferential voting. Since 2001, however, economic and socially conservative parties on the center and right have dominated the Polish political scene. According to traditional expectations, the emergence of these parties should have resulted in a decline in women's overall representation. In fact, women maintained the gains made in the 2001 election. This study examines the extent to which preferential voting in the Polish open-list system led to the maintenance of levels of women's representation despite an ideological turn to the right.

This study informs our previous understanding of open-list systems in three ways. First, I review differences across open-list systems to identify 
some of the factors that affect the inclusion of women in open-list systems. Second, rather than assuming that an open-list system operates in a consistent fashion within a country, I examine variation over time and across parties in the list construction and voters' use of preferential voting. Finally, I am able to document the extent to which women in Poland were elected as a result of parties' original list placements or through preferential votes.

\section{ELECTORAL SYSTEMS AND WOMEN'S DESCRIPTIVE REPRESENTATION}

In new democracies, electoral design decisions may reflect a country's historical experiences with the previous governments and the stature the country hopes to attain in global politics. In the postcommunist context, decisions about electoral design generally reflected the efforts of the communist parties or the recently democratically elected parties to maintain their own power, rather than the descriptive representation of social groups within parties and the legislatures (Birch et al. 2002; Nalewajko and Wesolowski 2008). As a result, women's overall representation in the new democracies of Eastern Europe was often much lower than under the previous communist system, where quotas ensured a minimum level of descriptive representation (Matland and Montgomery 2003; Rueschemeyer 2008; Saxonberg 2000). With subsequent elections, women's levels have risen in several postcommunist countries while they have stagnated or failed to increase in other countries. These patterns are attributed to a number of countryspecific factors (see Dubrow 2006; Irvine 2007; Rueschemeyer and Wolchik 2009), as well as factors common to all postcommunist nations, such as the presence of a PR system and/or national quotas (Gaber 2005; Kostadinova 2002, 2007; Matland and Montgomery 2003; Moser 2001; Saxonberg 2000).

Increasingly, researchers conclude that there are important differences in women's outcomes when nations are compared with closed, flexible, and open-list PR systems (Salmond 2006; Schmidt 2008). A closed-list PR format presents the voter with a choice of party-ranked candidates on electoral lists. Voters select which party they prefer and seats are assigned to parties on the basis of their share of the vote. Candidates gain access to seats based on their position on the party list. In an open-list PR format, voters select a candidate from a ranked or unranked party list of 
candidates. Seats assigned to parties reflect the candidates' share of the vote. Candidates also gain access to seats based solely on their share of the vote. Flexible formats assign seats to candidates by a combination of vote share and original party list placement.

\section{OPEN-LIST PROPORTIONAL REPRESENTATION SYSTEMS AND WOMEN'S DESCRIPTIVE REPRESENTATION}

While an abundance of research has focused on documenting the positive effect of closed-list PR systems on women's electoral outcomes, a more limited amount of research has focused on understanding the effects of an open-list system on women's representation. What is particularly distinct about the open-list system is the fact that voters must choose among candidates within the same party, thus engaging in what has been called preferential voting (Karvonen 2004), personal voting (Shugart 1994), or intraparty choice (Katz 1986). The fact that voters can and often must engage in preferential voting in open-list systems is expected to affect both the construction of the original list and the voters' response to the original list.

Scholars disagree on the probable effect of the open-list system on women's electoral outcomes. For example, Taagepera (1994) argues that the open-list format could theoretically help women, while Htun and Jones (2002) argue that women would be harmed because of their lower levels of resources. Country-specific studies in Finland (Holli and Waas 2010; Villodres 2003), Belgium (Meier 2008), and Peru (Schmidt 2008) offer mixed empirical evidence with respect to women's inclusion on open lists and electoral outcomes. Looking across these country-specific studies and building on broader theoretical ideas put forward on the effects of electoral systems on women's representation (Grofman and Lijphart 1986; Rule and Zimmerman 1994; Tremblay 2008), I focus on three critical factors that may explain why women can do well in some open-list systems but may not do as well in other open-list systems: intraparty competition for list positions, the necessity for and utility of candidate campaigns, and voter's behaviors toward the electoral lists.

These same factors can also be used to understand differences in the effects of open-list systems across parties in the same election or over time in a single country. For example, does the average position of women within the party move up or down when intraparty competition increases? Are supporters of one party more or less likely to shift the 
original list positions than are supporters of another party? In the following sections, I review existing evidence on the effects of parties, candidates, and voters in open-list systems on women's electoral outcomes.

\section{The Role of the Party in Open-List Systems}

The importance and function of the party vary across different types of open-list systems. An important difference in the role of parties is that some countries require parties to present a ranked list of candidates (e.g., Poland), while others do not (e.g., Finland). Ranked lists provide voters with important cues as to the order in which parties prefer candidates to be elected. Prior research has demonstrated that candidates at the top of lists have a distinct advantage over those at the bottom (Lutz 2010; Villodres 2003). As a result, intraparty competition for list positions will occur in systems with ranked lists, such as those found in Poland (Rauino 2007; Schmidt 2008).

Research on candidate selection within parties has shown that women often have more limited resources (Htun and Jones 2002) and that male party leaders are reluctant to support female candidates (Cheng and Tavits 2011; Tremblay and Pelletier 2001). In fact, Matland (2005, 105) concludes in the context of Poland that "party leaders undervalue women candidates, either because of sexism among members of the selection committees or, possibly, because members of selection committees have a misplaced fear of sexism on the part of the voter." Evidence of parties' reluctance to support female candidates in Poland was found in an examination of party lists between 1989 and 1997, where equally qualified women were placed lower on most party lists than their male counterparts (Kunovich 2003).

Thus, women are at a disadvantage in systems that cultivate intraparty competition, and women are particularly disadvantaged in parties where the competition is most intense. The negative effect of intraparty competition on women's selection and list placement can be overcome or reduced in two ways. First, national laws, such as quotas, can be established to force parties to provide greater opportunities for women's meaningful inclusion on electoral lists (Krook 2009). Prior to November 2010, there was no national quota law in Poland. Second, the negative effect of intraparty competition might also be reduced if parties make a clear commitment to the inclusion of women. Kittilson (2006) demonstrates that parties on the left are generally more likely to do this 
than parties on the right. However, Siemienska (2005) found that only a few parties in Poland had made a commitment to women's inclusion by means of sex-specific goals on electoral lists. Through a process of contagion, additional parties may adopt a more inclusive policy toward female candidates over time (Cowell-Meyers 2011; Matland 2005). There is evidence that during the elections under consideration, several of the Polish parties changed their position on female candidates.

The data presented here will examine the extent to which parties support female candidates in Poland, whether variation in support falls along the traditional left/right ideological spectrum, and whether variation over time is a function of intraparty competition and/or a process of contagion.

\section{The Role of the Candidate in the Open-List System}

Carey and Shugart (1995) previously hypothesized that there is an incentive in open-list systems for candidates to cultivate a personal reputation and, when possible, to have direct contact with constituents. Incumbents might do this by providing direct constituent-services "pork" and patronage (Shugart 1994), and well-known local residents might do this through personal and professional networks. The necessity for and utility of individual campaigning, therefore, may be important for understanding how open-list systems affect women's representation.

Some open-list systems require that voters choose a candidate (e.g., Poland), whereas other systems permit but do not require voters to choose a candidate (e.g., Belgium). Scholars generally find that when the system does not require voters to choose a candidate, voters maintain the existing list order (Meier 2008) or only a subset of well-informed and higher-status voters engage in optional preferential voting (Schmidt 2008). On the other hand, when the system requires voters to choose among candidates within a party, there is evidence to suggest that preferential voting matters because voters respond to particular candidates (Marsh 2007). As a result, individual campaigns matter most in open-list systems, which require voters to select candidates.

Within these types of open-list systems, the necessity for campaigning and the effectiveness of campaigns will vary across parties and candidates. Due to the focus on party campaigns, there has been only limited research on candidate campaigns in Poland. Two pieces of evidence, however, suggest that Polish parties and politicians believe that individual campaigns are necessary and important. First, research on 
campaign funding and finances concludes that the importance of individual candidate expenditures has increased over time and varies across parties (Walecki 2005). Second, incumbents and candidates often engage in party switching. As a feature of this switch, the new party will place incumbents from other parties on its electoral lists in competitive positions (Shabad and Slomczynski 2004; Zielinski, Slomczynski, and Shabad 2005). Parties do this because they expect that these candidates have their own supporters and that their votes will help the party gain additional seats within that district.

Candidates placed lower on the list have the greatest incentive to campaign on their own behalf. Since women with more comparable qualifications are more likely to be placed farther down a list than a male candidate, the female candidate has the most incentive to campaign. One way to determine objectively if candidate campaigns are effective is to examine the extent to which candidates move up or down the electoral list after preferential voting has occurred. The data presented here will examine the extent to which female candidates experience positive mobility across parties and over time.

\section{The Role of the Voter in Open-List Systems}

The role of voters in electing female candidates varies across open-list systems based on the number of candidates a voter can select and the extent to which enough voters choose the same candidate and breach the original list order. In open-list systems that allow voters to choose more than one candidate, voters can be persuaded to help women by splitting their votes for a male and a female candidate, whereas systems that permit only one vote require voters to choose between male and female candidates. For example, feminist nongovernmental organizations in Peru put forward the slogan "Of your two preferential votes, cast one for a woman" (Schmidt 2008, 166). On the other hand, research in Finland, where only one vote is allowed, finds that women are often negatively affected by gender-based voting in the open format because men are less likely to vote for women (Holli and Wass 2010).

Voters in Poland may choose only one candidate, and several factors suggest that voters would prefer men over women. While positive attitudes toward women in politics have increased over time, many in Poland continue to believe that politics is not a suitable profession for women (Siemienska 2009). In addition, socially conservative parties in Poland advocate for women to return or stay in the home to care for their families. 
Finally, the views of the Catholic Church and religious-based media support traditional gender roles within the family. The combined effect of individual attitudes, political parties, and cultural and religious institutions advocating for traditional gender roles within the family suggests that some Polish voters would be reluctant to vote for female candidates.

Even though a one-vote system may generally harm women, a one-vote system whereby seats are allocated solely on the basis of votes and not on a combination of votes and original list position may actually help coordinate and motivate interested voters. A unique aspect of this type of open-list system is that candidates may secure seats with only a small percentage of the votes in their particular districts. For example, if all 10 seats in a district went to a single party and $90 \%$ of votes went to the candidate in position 1 , then the remaining $10 \%$ of the district votes would determine the other 9 candidates. As a result, a candidate at the bottom of the list who is able to secure enough votes can easily outrank a candidate at the top of the list who did not campaign for his or her own votes.

Two pieces of research on Poland suggest that a small number of voters may in fact be responsible for shifting women positively up electoral lists after casting their votes. First, research on Polish voters finds that many identify with parties rather than candidates (Norris 2004, 239). As a result, most voters accept the party's preference for leadership and select the top candidate. A small number of voters are then able to overcome the party's preferences by voting farther down the list. In fact, having examined the data from 2001, Matland $(2005,105)$ concludes "that women do better with voters than they do with the party committees putting together party lists, that is, the preferential vote leads to greater representation of women." The data presented here will examine the extent to which preferential voting, rather than the original positions on electoral lists, resulted in women's elections. Furthermore, I examine variations across parties and over time.

\section{Summary}

Having reviewed theoretical and empirical work on the characteristics of open-list systems and how they affect women's representation in a variety of contexts, I focus my analysis of Poland on three fundamental questions: To what extent do Polish parties construct electoral lists that place women in positions with a greater likelihood of being elected? Do voters respond to women's original list placements by moving them up or down the electoral list? Finally, did preferential voting actually increase 
or decrease the number of women elected to the Polish national legislature (Sejm) in 2001, 2005, and 2007?

\section{POLCAN: DATA AND METHODS}

Prior to the 2001 election, substantial changes to electoral laws were made that included removing the use of a national list, reducing the number of electoral districts, and increasing the district magnitude of most districts. The three elections included in this analysis $(2001,2005,2007)$ were conducted under almost the exact same system, with the only difference being the vote-seat formula, which shifted back from the Sainte Lague, used in 2001, to the d'Hondt system for 2005 and 2007 (Millard 2006). Original data for each election were obtained from the Polish National Electoral Commission. The data were then combined into a single file, POLCAN, which follows all candidates who competed in elections between 1989 and 2007 for the Sejm.

Over time, the number of parties competing for seats has declined, the number of candidates has declined, and the number and specific parties gaining seats in the Sejm has become somewhat stable. Given this outcome, I restrict my presentation of findings to only those parties that were elected in either 2001, 2005, or 2007. Throughout this article, I use the Polish party abbreviations. I provide the standard English translations and a brief description of each party in Table 1. For ease of interpretation, parties are arranged from top to bottom in the remaining tables in order to indicate their relative position on an ideological continuum, ranging from secular to religious fundamentalist (Markowski 2006).

Based on the characteristics of lists and candidates' positions on lists, four concepts were created to measure women's inclusion in parties' and voters' response to female candidates. For every list, I calculate the percentage of female candidates, whether the list contained a woman in the top three positions, and the average movement among female candidates. Movement among candidates is measured by subtracting their original list position from their final list position according to voters' preferences. For example, if a party placed a candidate in position 3 on the original list but the candidate only received enough votes to secure position 7 , this candidate would be identified as having experienced a 4-point negative shift in list position. An example of positive movement would occur when a candidate originally in position 10 received enough votes to qualify for position 3, 
Table 1. Party abbreviations, English names, brief overview

\begin{tabular}{cc} 
Abbreviation English Name & $\begin{array}{c}\text { Brief History, Core Electorate, and } \\
\text { Ideological Position }\end{array}$ \\
\hline
\end{tabular}

\begin{tabular}{lll}
\hline SLD-UP & $\begin{array}{l}\text { Alliance of the Democratic } \\
\text { Left and Labor Union }\end{array}$ & $\begin{array}{l}\text { Emerged in } 2001 \text { as a coalition of two } \\
\text { traditional left parties with ties to the former } \\
\text { Communist Party. The coalition platform } \\
\text { changed regularly and party leaders were } \\
\text { largely discredited before the 2005 election. }\end{array}$ \\
LID $\quad$ Left and Democrats (SLD, & $\begin{array}{l}\text { Emerged in } 2006 \text { as a center left coalition. } \\
\text { The goal was to provide voters with an } \\
\text { alternative to the two dominant parties, PiS } \\
\text { and PO. The coalition represented } \\
\text { traditional left party program appeals and was } \\
\text { headed by the former Polish president, } \\
\text { Aleksander Kwasniewski. }\end{array}$
\end{tabular}

Samoobrona Self-Defense of the Republic of Poland

Emerged in 1993 as a left populist party. The platform generally appeals for protecting the economic fate of ordinary people and religious conservative social policies. The party strongly advocates for agrarian and trade union issues. Andrzej Lepper is the most well-known leader.

PSL Polish Peasant Party

Party existed during the communist regime and has participated in all subsequent elections. Advocated historically for rural interests and agricultural profession and industry. By 2007 shifted to focus more broadly on inequities between rural and urban districts and promoting interests of small entrepreneurs.

Emerged in 2001 as a liberal conservative party with roots in former Solidarity parties. The platform generally appeals to young, well-educated, urban dwellers and strongly advocates for privatization of remaining public sectors of economy. The most wellknown leader is Donald Tusk.

PiS Law and Justice

Emerged in 2001 as a conservative Catholic party that promotes policies to develop a national community with shared values, the Fourth Republic. The platform generally appeals to those who live in rural areas, did not benefit from economic transformations, and generally have lower levels of education. Kaczynski twins are the most well-known leaders. 
Table 1. Continued

\begin{tabular}{|c|c|c|}
\hline Abbreviation & English Name & $\begin{array}{c}\text { Brief History, Core Electorate, and } \\
\text { Ideological Position }\end{array}$ \\
\hline LPR & League of Polish Families & $\begin{array}{l}\text { Emerged in } 2001 \text { as a strongly conservative } \\
\text { populist party on the right. The platform } \\
\text { generally appeals the most to those with } \\
\text { strong ties to the Catholic Church and who } \\
\text { favor the central role of family to Polish } \\
\text { national identity. The party is strongly } \\
\text { supported by Radio Maryja and Roman } \\
\text { Giertych is the most well-known leader. }\end{array}$ \\
\hline
\end{tabular}

Note: See Jasiewicz 2008, Markowski 2006, and Markowski 2008 for a basic overview of Polish parties and voter support between 2001 and 2007.

thus experiencing a 7-point positive shift in list position. After calculating the three indicators for each list, I aggregate the findings for each party. This results in party-level measures of the percentage of female candidates, the percentage of lists with women in the top three positions, and the average movement of women after preferential voting occurred.

For all candidates, I determine if they were elected under their original list position or if they were elected due to preferential voting. I created this measure in a two-step process. On the basis of their share of the vote, I first identified how many seats a party won on any given list. All the candidates on that list were then identified as having been above or below the number of seats won. All candidates at or above the number of seats won were identified as having had the possibility of being elected on the basis of their original list positions, while candidates below the number were identified as having the possibility of being elected as a result of preferential voting. This measure was then interacted with a measure of having been elected. Using this measure, I document the percentage of members of the legislature/ parliament (MPs) who were elected as a result of their original list positions versus the percentage of MPs who were elected as a result of preferential voting on each list. I then calculate for each party the percentage of women elected due to their original list positions versus preferential voting.

\section{FINDINGS}

The following findings are organized in order to consider the role of the party, the candidate, and the voter. With the data currently available, I am able to examine descriptive patterns, but not formally test the causal 
mechanisms identified in this article. Therefore, I present the descriptive findings in this section and discuss probable explanations for the patterns in the discussion section. Additional data from future elections will be needed in order to test these ideas formally.

\section{The Role of Parties and Intraparty Competition}

Parties can support women in ranked open-list systems through the number of women selected as candidates and in their original list position. As a result of prior research, I expected to find that parties on the left would be more supportive of female candidates, that intraparty competition would negatively affect women's inclusion and placement, and that over time, additional parties would include more women and place women higher on their electoral lists.

Findings presented in Table 2 show that between 2001 and 2007, women comprised between $23 \%$ and $25 \%$ of candidates on average. In both 2001 and 2005, parties on the left clearly had more women in their ranks than parties in the center or on the right. In fact, the highest percentage of candidacies held by women in Poland was in the Alliance of the Democratic Left (SLD) in 2001. Variation across parties declined over time, with the Left substantially decreasing its support for female candidates and the center and right parties modestly increasing their support. By 2007, the left alliance, now called LID, had 22\% female candidates while the centrist right PO had $21 \%$.

As in most PR systems, the percentage of female candidates is generally not the best indicator of party support. Many parties in Poland put forward more candidates than can be elected, and with no national laws governing

Table 2. Support of female candidates by party in Poland, 2001, 2005, 2007

\begin{tabular}{lccccccc}
\hline & \multicolumn{3}{c}{$\begin{array}{c}\text { \% Women } \\
\text { on Electoral Lists }\end{array}$} & & \multicolumn{3}{c}{$\begin{array}{c}\text { \% Women } \\
\text { in Top Three Positions }\end{array}$} \\
\cline { 2 - 4 } \cline { 7 - 8 } & 2001 & 2005 & 2007 & & 2001 & 2005 & 2007 \\
\hline Average & 23.16 & 24.51 & 22.95 & & 41.44 & 51.52 & 53.72 \\
SLD/LID & 36.16 & 27.63 & 21.93 & & 51.22 & 53.66 & 36.59 \\
Samoobrona & 20.48 & 22.82 & 23.86 & & 36.59 & 57.50 & 63.41 \\
PSL & 19.61 & 19.65 & 18.15 & & 19.51 & 36.59 & 34.15 \\
PO & 17.08 & 20.96 & 20.99 & & 39.02 & 56.10 & 80.49 \\
PiS & 17.73 & 21.05 & 19.17 & & 34.15 & 56.10 & 58.54 \\
LPR & 24.90 & 19.45 & 20.38 & & 62.50 & 34.15 & 41.46 \\
\hline
\end{tabular}


women's access to winnable positions, parties can have the appearance of supporting women in numbers of candidates while women actually have a low likelihood of success. Looking at women's access to the top three positions on electoral lists provides additional insight into a party's level of support for female candidates.

Findings presented in Table 2 show that in 2001, $41 \%$ of all party lists contained at least one woman in a top-three position, and by $2007,54 \%$ of all party lists contained at least one woman in a top position. In 2001, only two parties - the left alliance, SLD, and the socially conservative, LPR - put forward lists with more than $50 \%$ of their top positions held by women. By 2007, significantly more parties across the political spectrum had put forward lists with women in top positions. The most dramatic changes in top positions occurred with the decline of support for women in the left alliance, LID, and the dramatic increase in support in PO.

\section{The Role of Candidates and Candidate Campaigning}

In an open-list system, candidates have a unique opportunity to campaign on their own behalf in an attempt to improve their list position. If they secure enough votes, the list can be breached and the order of election can be changed. On an aggregate level, voters can respond to women's presence on the lists either by moving them down the list, thus penalizing them, or by moving them up the list and increasing their likelihood of election. To assess the extent to which voters penalize or support female candidates, I measured the average movement of women across party lists.

Findings in Table 3 show that women in all three elections experienced positive movement, on average moving up slightly more than 1 position. Furthermore, across parties and over time, there are only two examples

Table 3. Average movement of female candidates on electoral lists by voters

\begin{tabular}{lccc}
\hline & $\begin{array}{c}2001 \\
\text { Average Movement }\end{array}$ & $\begin{array}{c}2005 \\
\text { Average Movement }\end{array}$ & $\begin{array}{c}2007 \\
\text { Average Movement }\end{array}$ \\
\hline Average & 1.15 & 1.06 & 1.16 \\
SLD/LID & -.37 & .78 & 1.47 \\
Samoobrona & 2.01 & 1.32 & 1.29 \\
PSL & .04 & -.35 & .16 \\
PO & 1.45 & 1.47 & 1.15 \\
PiS & 2.08 & .64 & 1.03 \\
LPR & 2.55 & 2.05 & 2.03 \\
\hline
\end{tabular}


of voters responding negatively to female candidates, in the left alliance SLD in 2001 and the socially conservative PSL in 2005. In 2001, the greatest average increase in women's list positions occurred among the supporters of the two most conservative parties, PiS and LPR. In fact, women within LPR consistently experienced the most positive movement across all three elections. While the average movement of women in LPR remained the same over time, women in other parties generally saw declines in the amount of average movement. For example, women in $\mathrm{PO}$ were moved up 1.45 positions in 2001 and by 2007 were moved up 1.15. This trend was reversed in two parties, SLD/ LID and PSL, where voters increased support for women over time. These findings clearly show that across parties and over time, female candidates were not penalized on average by voters.

\section{The Role of Voters and the Effect of Preferential Voting}

Knowing that women experienced positive movement on electoral lists is an important first step in establishing that preferential voting does not appear to harm women's electoral outcomes. This finding, however, does not demonstrate to what extent this movement matters for women's electoral outcomes. In order to assess if preferential voting affects women's electoral outcomes positively, I measured the proportion of women elected from within a party that was the result of their original list position versus the proportion elected because voters moved women up the list. Findings presented in Table 4 provide the number of seats won by women in the three elections. The number of women elected based on their original position is then provided separately from the number of women elected as result of preferential voting.

Women's overall representation in the national legislature has remained at $20 \%$ after the last three elections. The manner in which women were elected and the parties they represent have varied considerably during this time period. On average, preferential voting resulted in an increase in women's representation by $47 \%$ in $2001,22 \%$ in 2005 , and $25 \%$ in 2007. This average increase is particularly remarkable considering that women' representation as candidates had increased over time as well.

The findings presented in Table 4 also show important variation across parties in the role of preferential voting in electing women. In 2001, six parties were elected to the Sejm, and the left alliance, SLD, controlled almost half the seats. While more than half of all women elected were 
Table 4. Women's presence in the Sejm, 2001-2007, and method of election

\begin{tabular}{|c|c|c|c|c|c|c|c|}
\hline \multirow[b]{2}{*}{ Election } & \multicolumn{2}{|c|}{$\begin{array}{l}\text { Election } \\
\text { Outcomes }\end{array}$} & \multicolumn{3}{|c|}{ Seats Held by Women } & \multicolumn{2}{|c|}{$\begin{array}{c}\text { Due to Preferential } \\
\text { Voting }\end{array}$} \\
\hline & $\begin{array}{l}\text { Seats } \\
\text { Won }\end{array}$ & $\begin{array}{c}\% \\
\text { Female } \\
\text { MP }\end{array}$ & Total & $\begin{array}{c}\text { Elected } \\
\text { by Party } \\
\text { List }\end{array}$ & $\begin{array}{l}\text { Elected } \\
\text { by } P V\end{array}$ & $\begin{array}{c}\% \text { of } \\
\text { Women } \\
\text { Elected }\end{array}$ & $\begin{array}{c}\% \\
\text { Increase } \\
\text { in Seats }\end{array}$ \\
\hline 2001 & & 20.22 & 93.00 & 63.00 & 30.00 & 32.00 & 47.00 \\
\hline $\begin{array}{l}\text { SLD-UP } \\
\text { Samoobrona } \\
\text { PSL } \\
\text { PO } \\
\text { PiS } \\
\text { LPR }\end{array}$ & $\begin{array}{r}216.00 \\
53.00 \\
42.00 \\
65.00 \\
44.00 \\
38.00\end{array}$ & $\begin{array}{r}25.46 \\
16.98 \\
0.00 \\
20.00 \\
13.64 \\
26.32\end{array}$ & $\begin{array}{r}55.00 \\
9.00 \\
0.00 \\
13.00 \\
6.00 \\
10.00\end{array}$ & $\begin{array}{r}37.00 \\
8.00 \\
0.00 \\
8.00 \\
3.00 \\
7.00\end{array}$ & $\begin{array}{r}18.00 \\
1.00 \\
0.00 \\
5.00 \\
3.00 \\
3.00\end{array}$ & $\begin{array}{r}32.73 \\
11.11 \\
0.00 \\
38.46 \\
50.00 \\
30.00\end{array}$ & \\
\hline 2005 & & 20.43 & 94.00 & 77.00 & 17.00 & 18.00 & 22.00 \\
\hline $\begin{array}{l}\text { SLD } \\
\text { Samoobrona } \\
\text { PSL } \\
\text { PO } \\
\text { PiS } \\
\text { LPR }\end{array}$ & $\begin{array}{r}55.00 \\
56.00 \\
25.00 \\
133.00 \\
155.00 \\
34.00\end{array}$ & $\begin{array}{r}18.71 \\
26.79 \\
4.00 \\
24.81 \\
18.71 \\
14.71\end{array}$ & $\begin{array}{r}11.00 \\
15.00 \\
1.00 \\
33.00 \\
29.00 \\
5.00\end{array}$ & $\begin{array}{r}10.00 \\
10.00 \\
1.00 \\
27.00 \\
24.00 \\
5.00\end{array}$ & $\begin{array}{l}1.00 \\
5.00 \\
0.00 \\
6.00 \\
5.00 \\
0.00\end{array}$ & $\begin{array}{r}9.09 \\
33.33 \\
0.00 \\
18.18 \\
17.24 \\
0.00\end{array}$ & \\
\hline 2007 & & 20.43 & 94.00 & 75.00 & 19.00 & 20.00 & 25.00 \\
\hline $\begin{array}{l}\text { LID } \\
\text { Samoobrona } \\
\text { PSL } \\
\text { PO } \\
\text { PiS } \\
\text { LPR }\end{array}$ & $\begin{array}{r}53.00 \\
0.00 \\
31.00 \\
209.00 \\
166.00 \\
0.00\end{array}$ & $\begin{array}{r}3.23 \\
22.97 \\
20.48\end{array}$ & $\begin{array}{r}1.00 \\
48.00 \\
34.00\end{array}$ & $\begin{array}{r}1.00 \\
38.00 \\
28.00\end{array}$ & $\begin{array}{r}0.00 \\
10.00 \\
6.00\end{array}$ & $\begin{array}{r}0.00 \\
20.83 \\
17.65\end{array}$ & \\
\hline
\end{tabular}

from SLD (55 out of 93), women comprised only $25 \%$ of SLD members in the legislature. The remaining women were distributed across four other parties, and PSL had no female representatives in 2001. Even with SLD's strong support of female candidates, $32 \%$ of the women were elected after voters breached the original list order. In addition to increasing women's representation on the left, preferential voting played an even more important role in electing women to socially and economically conservative parties. For example, $50 \%$ of female representatives from PiS were elected by voters and 38\% of female representatives from PO. As previously noted by other scholars, preferential voting played a critical role in the election of women across all parties during the 2001 election. 
After 2001, the proportion of women elected from preferential votes does decline from $47 \%$ to $22 \%$ in 2005 . In 2005 , all elected parties had at least one female member and women were distributed more evenly across parties, with a heavier concentration in the two dominant parties, PO and PiS. The importance of preferential voting varied across parties, again with SLD voters responsible for electing only 1 of the 11 women, while Samoobrona voters were responsible for electing 5 out of their 15 female representatives.

After the 2007 elections, there was a modest increase in the role of preferential voting, with $25 \%$ of female members having been elected by the voters. Women comprised $20 \%$ of the party delegates for three of the four parties elected, and only one woman was elected from PSL. Voters for both parties in the left alliance, LID and the center PO, increased the presence of women by more than $20 \%$. In comparison to 2005, voters on the left found it necessary to shift more women up the lists to a positive position. These findings clearly show that voters play a critical role in the election of women by voting for female candidates farther down the list across almost all parties in Poland.

\section{DISCUSSION}

Women's representation in the Polish Sejm increased greatly between 1997 and 2001. This increase was attributed to a number of factors, including the positive effect of preferential voting (Matland 2005; Siemienska 2003). The electoral success of center and right parties in 2005 and 2007 should have negatively affected women's levels of representation, but it did not. The research presented here provides evidence that preferential voting once again played an important role in explaining women's political outcomes in Poland. In fact, preferential voting increased the percentage of women elected to the Sejm by $20 \%$ to $30 \%$. These findings document that all parties consistently underestimate support for female candidates and that voters regularly shift women far enough up the list that an unexpected number of female candidates are elected.

I previously identified several ways that parties, candidates, and voters have been found to influence women's election outcomes in open-list systems. The descriptive data presented for Poland provides rich documentation of women's inclusion on lists, voters' average response to 
women on lists, and whether preferential voting actually matters. Unfortunately, these data do not allow me to examine the specific processes and causal mechanisms that would explain the observed patterns. Therefore, I offer a discussion of how these mechanisms might have operated in Poland at that time. Scholars will need to collect additional data to test these ideas.

How do the dynamics within parties and between parties affect women's positions on electoral lists and their ultimate outcomes in open-list systems? I expected to find support for female candidates to vary over time and across parties as a result of changes in intraparty competition for list positions and a process of contagion. The data presented in Figure 1 partially support these expectations. Figure 1 documents support for female candidates in three distinctive parties over the last three elections, the far right LPR, the center right PO, and the left SLD/LID. The first three sets of bars display the average percentage of women on the electoral lists, and the second three sets of bars display women's average percentage in the top three positions. The success of the Left in 2001 should have shown other parties that having a significant number of women on electoral lists does not negatively affect voter support and should have produced an average increase in women's presence on lists over time. This does not occur. While the center right party PO increases women's average presence slightly, both SLD/LID and LPR actually reduce their average levels of inclusion of women on lists over time.

While the process of contagion clearly did not convince other parties to include more women on their lists in general, it may have influenced PO's

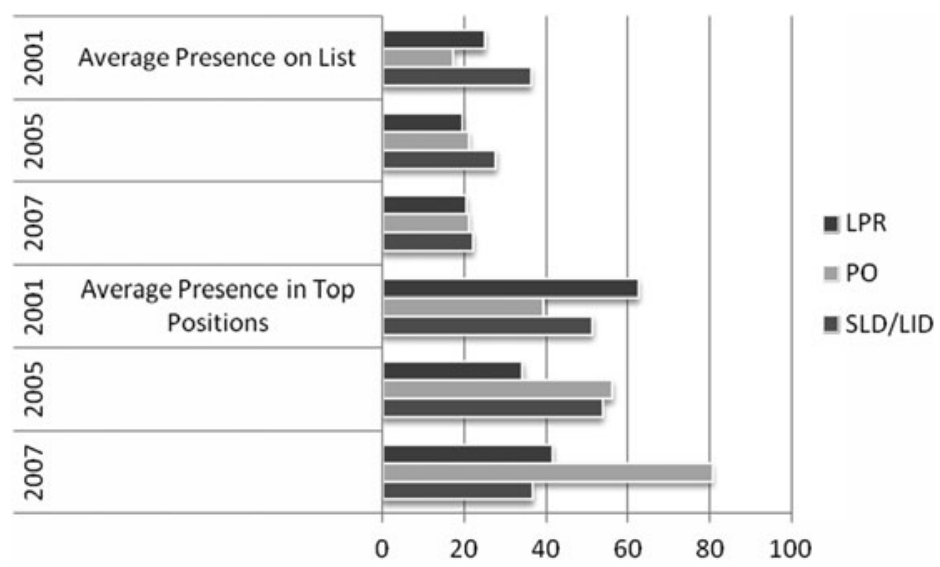

FigURE 1. Inclusion of women on party lists (percentages). 
strategic and distinctive decision to include more women in top positions. PO recognized that the SLD policy to set a minimum threshold for women appealed to voters on the left and, in fact, adopted a similar policy to attract SLD voters during the 2005 election. A look at the positive list movement of their own female candidates in 2001 would have also convinced PO leaders that there was little risk to such a strategy with their core constituents. By 2007, PO further increased their support of female candidates by including women in one of the top three positions on $80 \%$ of their lists. This strategy was used again to clearly distinguish itself further from another party on the right, $\mathrm{PiS}$, and to shift support among female voters from PiS to PO. This strategy worked again, as the gap in women's vote increased between PO and PiS (Markowski 2008).

While women's average presence on lists remains basically the same or experiences declines over time, women's average presence in top positions changes in party-specific ways that may be a function of intraparty competition. The center right party with the fewest women in top positions in 2001, PO, has the most women in top positions by 2007, and support from the left alliance, SLD/LID, actually declines over time. Intraparty competition is clearly a function of many factors, and two of these, expected voter support and party fragmentation, seem to explain some of the patterns presented in Figure 1. The decline in support for female candidates on the left and the increasing support in the center right, mirrors the parties' predicted levels of voter support in 2005 and 2007. The data also suggest that women's representation within a party may decline during those elections when there is fragmentation of leadership or a divided party platform. The League of Polish Families, LPR, emerged in 2001 with a clear and narrowly defined party identity that focused on traditional roles for women in society. Despite this traditional orientation toward gender roles, women's position within the party was strongest during the 2001 election, but over time, as intraparty competition for leadership heightened and debates over party platform increased, women's presence on the lists declined. On the other hand, Civic Platform (PO), which also emerged in 2001, was at first a party combined of various leaders from other parties and had a much less clear platform with regards to women. As PO developed a cohesive party platform and strong party leadership emerged, women's original position on the lists improved.

Scholars should gather data on the construction of electoral lists in Poland - that is, identifying factors that influence the construction of the list within parties and across parties, such as party rules for list 
construction at the national and regional level, as well as the sex composition of party leadership. In addition, future research might also consider identifying and measuring the extent to which parties strategically use female candidates in particular districts to increase their vote share.

How do the behaviors of candidates and voters affect female candidates' movement on electoral lists and their ultimate outcomes in open-list systems? Their overall positive movement across almost all parties in the three elections suggests that female candidates can campaign for themselves and that voters respond to the campaigns (see data in Table 3). There is also evidence, however, that the presence of women in top positions influences the average movement of women on electoral lists and ultimately the percentage of women elected through preferential voting. In Figure 2, I present line graphs for women's presence in top positions, their average movement on lists, and the relationship between presence in top positions and percentage elected by voters for the SLD/LID alliances and PO. Panel A and Panel B of Figure 2 show that as the presence of women in top positions in $\mathrm{PO}$ increases, there is a decline in average list movement in PO. The opposite pattern is observed in the left alliance; as women's presence in top positions declines, the average movement of women increases.

The graphs in Panel $\mathrm{C}$ document a similar pattern in the relationship between women's presence in top positions and the percentage of women elected through preferential voting. As more women were placed in top positions on electoral lists in PO, a smaller percentage of $\mathrm{PO}$ women were elected by breaching the original lists; the opposite pattern is observed in SLD/LID. Across the parties, the overall trend is for a smaller proportion of women to be elected as a result of preferential voting over time (see data in Table 4). That said, preferential voting continues to make significant contributions in particular parties and in particular regions in Poland. For example, in 2007 SLD voters were responsible for electing $27 \%$ of the female MPs (3 out of 11 ), and PO voters were responsible for electing $21 \%$ of the female MPs (10 out of 48).

Future research needs to focus on explaining how candidates in the Polish open-list system campaign on their own behalf and how women in particular appeal to voters. It would also be beneficial to understand the extent to which having a woman in a top list position affects voters' decisions to breach the original list in order to vote for alternative women farther down the list. Opportunities to examine individual candidate outcomes in Poland have been constrained by data availability. To my 
Panel A: Women's Presence in Top Positions on Electoral Lists
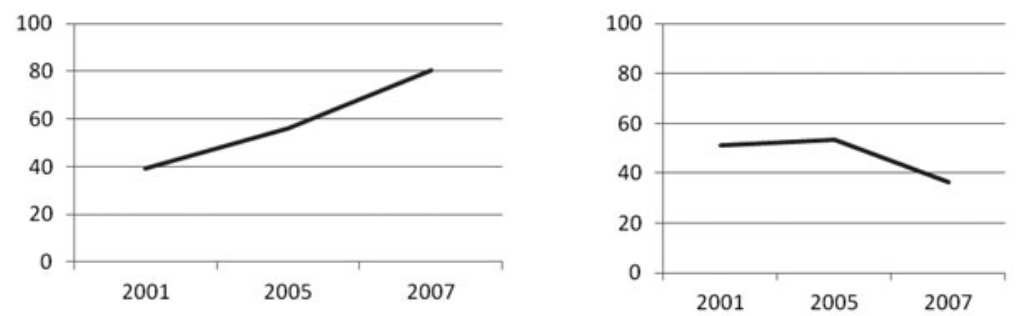

Panel B: Women's Average Movement on Electoral Lists
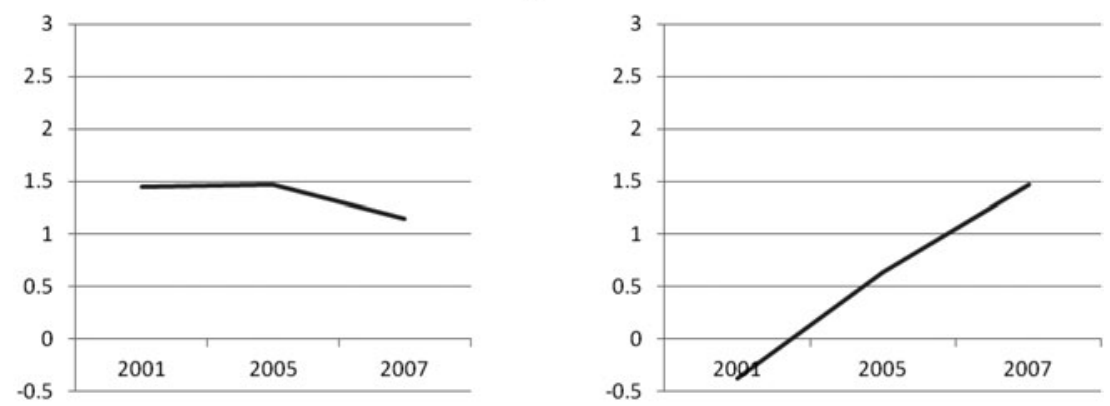

Panel C: Percentage of Women in Top Positions and Percentage of Women Elected by Preferential Voting
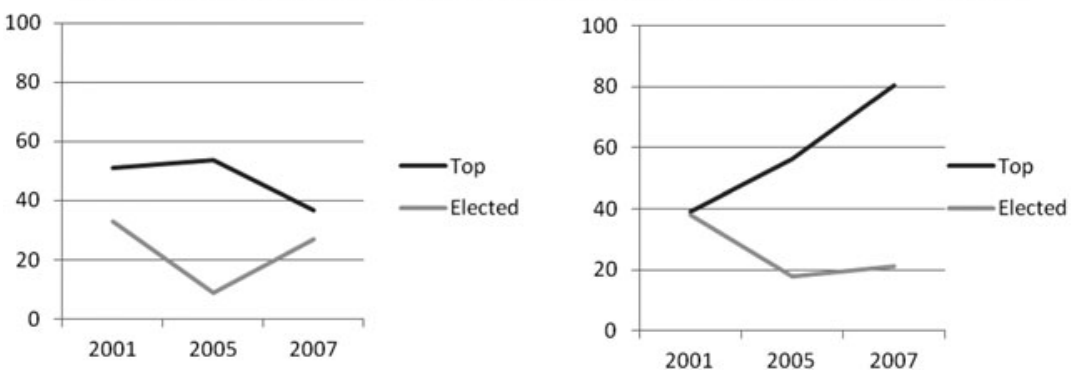

FIGURE 2. Voters's response to women's presence in top positions

knowledge, very little data exist that ask voters to identify which candidates they supported, rather than which parties they supported. The vibrant body of research in Poland on party support needs to be complemented by research on candidate support. Understanding which candidates are chosen by voters might offer greater insight into why women are moving up the list in certain parties. For example, Holli and Waas (2010) found that gender-based voting occurs in the context of the Finnish open 
system. This provides a reasonable explanation in Poland as well, where parties with stronger female voter support might also be the parties with the greatest proportion of female candidates elected by breaching the list.

Finally, the experiences of women in PO and SLD add additional support to a growing body of research that finds women's political presence increasing in parties other than the traditional Left (e.g., Childs, Webb, and Marthaler 2009; Hinojosa 2009). This pattern is the result of both the voters and the parties in the Polish case. If it were not for Polish voters on the center and right, women's levels of representation in the Sejm would have declined once again in 2005 and 2007. Future research needs to explain the basis on which center parties recruit and support female candidates and how women make inroads with voters in parties that profess a commitment to traditional roles for women. The most extreme example in Poland is the LPR, League of Polish Families, which has the highest average movement by women in all three elections.

Overall, the data presented here clearly show the dynamic nature of an open-list system, with parties constructing the original lists, candidates campaigning in order to improve their list positions, and voters often responding by breaching the original list positions. The experience of women in Poland documents a pattern whereby a lack of party support for female politicians results in an increased role of preferential voting in the election of women. When parties increase the proportion of women in top positions, women experience less positive mobility on average, and ultimately fewer are elected as a result of preferential voting. That said, the substantial numbers of women that are still elected through preferential voting indicates that Polish parties continue to underestimate voters' support of women and place women too low on electoral lists.

\section{CONCLUSION}

We often treat the effects of electoral systems on women's representation as being consistent over time and across parties in a single context. These data show that this is not always the case. While preferential voting explained more than $30 \%$ of women elected in some years, it explained only $20 \%$ in others. Within a single election, preferential voting explained $11 \%$ of female candidates within a party, while it explained $50 \%$ in another party. Similar to conclusions drawn about Peru (Schmidt 2008) and 
somewhat in contrast to those in Belgium (Meier 2008), I did not find systematic evidence that having an open-list system was an obstacle to women's election in Poland. In fact, I found that voters across the political spectrum positively shifted female candidates up the electoral list. Many parties often responded to positive shifts in the previous election by increasing the percentage of women in top positions on their subsequent lists. Nonetheless voters continued to shift women positively, albeit at a lower rate.

Not only do these data provide general insight into open-list systems, but they also help us understand women's electoral outcomes in postcommunist countries and in consolidating democracies. Despite an increase in the percentage of women in top positions on electoral lists, positive change in women's overall representation in Poland has stagnated over the last three elections. These data document that even though several parties have increased their commitment to women's inclusion, voters still find it necessary to select female candidates further down electoral lists. A recent change in Polish electoral laws will force and challenge parties to be more inclusive of women on their electoral lists. In November 2010, the Polish legislature passed a 35\% national quota law for all parties. This change will provide another unique opportunity to consider how parties and voters will respond to the increased presence of female candidates in the 2011 election. Although parties drive women's representation in PR fixed-list systems and voters drive women's representation in majority-rule systems, many open-list systems allow both the party and the voter to play important roles. As a result, open-list systems should be viewed as a unique opportunity to simultaneously consider the roles of voters and parties in the election of female candidates.

Sheri Kunovich is Associate Professor of Sociology at Southern Methodist University, Dallas, TX: kunovich@smu.edu

\section{REFERENCES}

Birch, Sarah, Frances Millard, Marina Popescu, and Kieran Williams. 2002. Embodying Democracy: Electoral System Design in Post-Communist Europe. New York: Palgrave Macmillan.

Carey, John M., and Matthew S. Shugart. 1995. "Incentives to Cultivate a Personal Vote: A Rank Ordering of Electoral Formulas." Electoral Studies 14: 417-39.

Cheng, Christine, and Margit Tavits. 2011. "Informal Influences in Selecting Female Political Candidates.” Political Research Quarterly 64 (2): 460-71. 
Childs, Sarah, Paul Webb, and Sally Marthaler. 2009. "The Feminisation of the Conservative Parliamentary Party: Party Members' Attitudes." Political Quarterly 80 (2): $204-13$.

Cowell-Meyers. 2011. “A Collarette on a Donkey: The Northern Ireland Women's Coalition and the Limitations of Contagion Theory." Political Studies. 59 (2): 411-31.

Dubrow, Joshua Kjerulf. 2006. "Women's Representation in the Romanian Chamber of Deputies, 1992-2005." International Journal of Sociology 36 (1): 95-111.

Gaber, Milica Antic. 2005. "Overview of Quota Systems in the Region of Central and Eastern Europe." In The Implementation of Quotas: European Experiences, ed. Julie Ballington and Francesca Binda. Stockholm: International IDEA Publications. $24-31$.

Grofman, Bernard, and Arend Lijphart. 1986. Electoral Laws and Their Consequences. New York: Agathan.

Hinojosa, Magda. 2009. "Whatever the Party Asks of Me: Women’s Political Representation in Chile’s Unión Demócrata Independiente.” Politics \& Gender 5 (September): $377-$ 408.

Holli, Anne Maria, and Hanna Wass. 2010. “Gender-Based Voting in the Parliamentary Elections of Finland." European Journal of Political Research 49 (5): 598-630.

Htun, Mala N., and Mark P. Jones. 2002. "Engendering the Right to Participate in Decisionmaking: Electoral Quotas and Women's Leadership in Latin America." In Gender and the Politics of Rights and Democracy in Latin America, ed. Nikki Craske and Maxine Molyneux. London: Palgrave, 32-56.

Irvine, Jill. 2007. "From Civil Society to Civil Servants: Women's Organizations and Critical Elections in Croatia." Politics \& Gender 3 (1): 7-32.

Jasiewicz, Krzysztof. 2008. “The New Populism in Poland: The Usual Suspects?” Problems of Post-Communism 55 (3): 7-25.

Karvonen, Lauri. 2004. "Preferential Voting: Incidence and Effects." International Political Science Review 25 (2): 203-26.

Katz, Richard S. 1986. "Intraparty Preference Voting.” In Electoral Laws and Their Electoral Consequences, ed. B. Grofman and A. Lijphart. New York: Agathon, 85-103.

Kittilson, Miki Caul. 2006. Challenging Parties, Changing Parliaments: Women and Elected Office in Contemporary Western Europe. Columbus: The Ohio State University Press.

Kostadinova, Tatiana. 2002. "Do Mixed Electoral Systems Matter? A Cross-National Analysis of Their Effects in Eastern Europe." Electoral Studies 21 (1): 23-34.

_. 2007. "Ethnic and Women's Representation under Mixed Election Systems." Electoral Studies 26 (2): 418-31.

Krook, Mona Lena. 2009. Quotas for Women in Politics: Gender and Candidate Selection Reform Worldwide. Oxford: Oxford University Press.

Kunovich, Sheri. 2003. "The Representation of Polish and Czech Women in National Politics: Predicting Electoral List Position." Comparative Politics 35 (3): 273-91.

Lutz, Georg. 2010. "First Come, First Served: The Effect of Ballot Position on Electoral Success in Open Ballot PR Elections." Representation 46 (2): 167-81.

Markowski, Radoslaw. 2006. "The Polish Elections of 2005: Pure Chaos or a Restructuring of the Party System.” West European Politics 29 (4): 814-32.

— . 2008. "The 2007 Polish Parliamentary Election: Some Structuring, Still a Lot of Chaos." West European Politics 31 (5): 1055-68.

Marsh, Michael. 2007. "Candidates or Parties? Objects of Electoral Choice in Ireland." Party Politics 13 (4): 500-27.

Matland, Richard E. 2005. "Enhancing Women's Political Participation: Legislative Recruitment and Electoral Systems." In Women in Parliament: Beyond Numbers: A 
Revised Edition, ed Julie Ballington and Azza Karam. Stockholm: International IDEA Publications 93-111.

Matland, Richard E., and Kathleen Montgomery. 2003. Women's Access to Political Power in Post-Communist Europe. Oxford: Oxford University Press.

Meier, Petra. 2008. "Belgium: The Collateral Damage of Electoral System Design.” In Women and Legislative Representation: Electoral Systems, Political Parties, and Sex Quotas, ed. Manon Tremblay. New York: Palgrave MacMillan, 137-47.

Millard, Frances. 2006. "Poland's Politics and the Travails of Transition after 2001: The 2005 Elections.” Europe-Asia Studies 58 (7): 1007-31.

Moser, Robert C. 2001. "The Effects of Electoral Systems on Women's Representation in Post-Communist States." Electoral Studies 20 (3): 353-69.

Nalewajko, Ewa, and Wlodzimierz Wesolowski. 2008. "Five Terms of the Polish Parliament, 1989-2005." In Post-Communist and Post-Soviet Parliaments: The Initial Decade, ed. David M. Olson and Philip Norton. London: Routledge, 48-71.

Norris, Pippa. 2004. Electoral Engineering: Voting Rules and Political Behavior. Cambridge: Cambridge University Press.

Paxton, Pamela, Melanie M. Hughes, and Matthew A. Painter II. 2010. "Growth in Women's Political Representation: A Longitudinal Exploration of Democracy, Electoral System and Gender Quotas." European Journal of Political Research 49: $25-52$.

Rauino, Tapio. 2007. “Open List, Open Mandate? Links Between MEPS and Parties in Finland." Perspectives on European Politics and Society 8 (2): 131-46.

Rueschemeyer, Marilyn. 2008. “Women's Participation in Post-communist Politics.” In Central and East European Politics: From Communism to Democracy, ed. Sharon L. Wolchik and Jane L. Curry. Lanham, MD: Rowman \& Littlefield, 113-28.

Rueschemeyer, Marilyn, and Sharon L. Wolchik. 2009. Women in Power: Post -Communist Parliaments. Bloomington: Indiana University Press.

Rule, Wilma, and Joseph Francis Zimmerman. 1994. Electoral Systems in Comparative Perspectives: Their Impact on Women and Minorities. Westwood, CT: Greenwood.

Salmond, Rob. 2006. "Proportional Representation and Female Parliamentarians." Legislative Studies Quarterly 31 (2): 175-204.

Saxonberg, Steven. 2000. "Women in East European Parliaments." Journal of Democracy 11 (2): $145-58$.

Schmidt, Gregory. 2008. "Peru: Success under Open List PR: The Election of Women to Congress." In Women and Legislative Representation: Electoral Systems, Political Parties, and Sex Quotas, ed. Manon Tremblay. New York: Palgrave MacMillan, 161-76.

- 2009. "The Election of Women in List PR Systems: Testing the Conventional Wisdom.” Electoral Studies 28 (2): 190-203.

Shabad, Goldie, and Kazimierz M. Slomczynski. 2004. "Inter-Party Mobility among Parliamentary Candidates in Post-Communist East Central Europe." Party Politics 10 (2): $151-76$.

Shugart, Matthew S. 1994. "Minorities Represented and Unrepresented." In Electoral Systems in Comparative Perspective: Their Impact on Women and Minorities, ed. Wilma Rule and Joseph F. Zimmerman, 31-4l.

Siemienska, Renata. 2003. "Women in the Polish Sejm: Political Culture and Party Politics versus Electoral Rules." In Women's Access to Political Power in PostCommunist Europe, ed. Richard E. Matland and Kathleen Montgomery. Oxford: Oxford University Press.

- 2005. "Gender Party Quotas in Poland." In The Implementation of Quotas: European Experiences, ed. Julie Ballington and Francesca Binda. Stockholm: International IDEA Publications 80-85. 
2009. "Women's Representation in the Polish Parliament and the Determinants of Their Effectiveness." In Women in Power: Post-Communist Parliaments, ed. Marilyn Rueschemeyer and Sharon L. Wolchik. Bloomington: Indiana University Press, 61-92.

Taagepera, Rein. 1994. "Beating the Law of Minority Attrition." In Electoral Systems in Comparative Perspective: Their Impact on Women and Minorities, ed. Wilma Rule and Joseph F. Zimmerman, 235-46.

Tremblay, Manon. 2008. Women and Legislative Representation: Electoral Systems, Political Parties, and Sex Quotas. New York: Palgrave MacMillan.

Tremblay, Manon, and Rejean Pelletier. 2001. "More Women Constituency Party Presidents: A Strategy for Increasing the Number of Women Candidates in Canada?" Party Politics 7 (2): 157-90.

Villodres, Carmen Ortega. 2003. "Intra-Party Competition under Preferential List Systems: The Case of Finland." Representation 40 (1): 55-66.

Viterna, Jocelyn, Kathleen M. Fallon, and Jason Beckfield. 2008. "How Development Matters: A Research Note on the Relationship between Development, Democracy, and Women's Political Representation." International Journal of Comparative Sociology 49 (6): 455-77.

Walecki, Marcin. 2005. Money and Politics in Poland. Warsaw: Fundacja Instytut Spraw Publicznych.

Zielinski, Jakub, Kazimierz M. Slomczynski, and Goldie Shabad. 2005. "Electoral Control in New Democracies: The Perverse Incentives of Fluid Party Systems.” World Politics 57 (April): 365-95. 